\title{
Motivating factors in hospital environmental management programs: a multiple case study in four private Brazilian hospitals
}

\author{
JAN KRÜGER

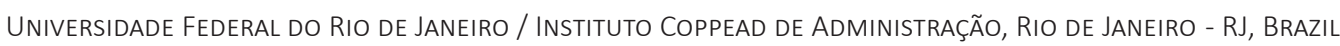 \\ Claudia ARAúJo \\ UNIVERSIDAdE FEDERAL do RIO dE JANEIRO / INSTITUTO COPPEAD DE ADMINISTRAÇÃO, RIO DE JANEIRO - RJ, BRAZIL
}

GUILHERME CURI

UnIVERSIDADE FEDERAL do RIO DE JANEIRO / INSTITUTO COPPEAD DE ADMINISTRAÇÃO Programa de Pós-Graduação em Comunicação e Cultura, Rio de Janeiro - RJ, Brazil

\begin{abstract}
Environmental responsibility has been a widespread and relatively recent research theme in the healthcare sector. Considering that the greater life expectancy increases the need for healthcare services and that these services produce negative environmental externalities on human health, it is important to understand the relationship between environmental responsibility and the healthcare sector. This article aims to investigate what motivates hospital managers to adopt environmental responsibility programs and to identify the actions implemented by them. A multiple case study was conducted involving four Brazilian hospitals based in Rio de Janeiro and São Paulo. The results indicate that the main drivers are competitive, ethical and regulatory and that the competitive and regulatory motivators have the potential to establish a baseline for environmental performance that varies across ownership type (public or private). The results also indicate that the comprehensiveness of environmental actions is related to organizational resilience and to the motivators that drive hospitals to adopt those actions. Two conceptual models are proposed to illustrate these findings and offer bases for further research.
\end{abstract}

Keywords: Hospital. Sustainability. Environment. Organizational resilience. Actions.

\section{Fatores motivadores dos programas de gestão ambiental em hospitais: um estudo de caso múltiplo em quatro hospitais privados brasileiros}

\section{Resumo}

A responsabilidade ambiental é um tema de pesquisa amplo e relativamente recente no setor de saúde. Tendo em vista que o aumento da expectativa de vida implica maior necessidade de serviços médicos e que estes, por sua vez, geram externalidades ambientais com efeitos negativos sobre a saúde, é necessária uma compreensão mais profunda da relação entre responsabilidade ambiental e o setor de saúde. Este artigo tem por objetivo investigar o que motiva os gestores de hospitais a buscar e adotar programas de responsabilidade ambiental e identificar as ações implementadas por eles. Um estudo de caso múltiplo foi conduzido em quatro hospitais brasileiros, localizados no Rio de Janeiro e em São Paulo. Os resultados indicam que os principais impulsionadores são concorrência, ética e regulação e que os motivadores concorrência e regulação têm o potencial para estabelecer uma base para o desempenho ambiental, que varia de acordo com tipo de propriedade (pública ou privada). Os resultados também indicam que a abrangência das ações ambientais está relacionada com a resiliência organizacional e com os motivadores que impulsionam hospitais para adotar essas ações. Dois modelos conceituais são propostos para ilustrar estas conclusões e oferecer bases para futuras pesquisas.

Palavras-chave: Hospital. Sustentabilidade. Meio-ambiente. Resiliência Organizacional. Ações.

Factores motivadores de los programas de gestión ambiental en hospitales: un estudio de caso múltiple en cuatro hospitales privados brasileños

\begin{abstract}
Resumen
La responsabilidad ambiental es un tema de investigación amplio y relativamente reciente en el sector de la salud. Considerando que la mayor esperanza de vida genera la necesidad de más servicios médicos y que estos, a su vez, generan externalidades ambientales con efectos negativos sobre la salud humana, es necesaria una comprensión más profunda de la relación entre responsabilidad ambiental y el sector de salud. Así, este artículo tiene como objetivo investigar las principales razones que motivan a los gestores de hospitales a adoptar programas de responsabilidad ambiental e identificar las acciones implementadas por ellos. Se llevó a cabo un estudio de caso múltiple en cuatro hospitales de Rio de Janeiro y São Paulo. El estudio reveló que los principales factores de motivación son de carácter competitivo, ético y reglamentario, y que los motivadores competitivos y reglamentarios tienen potencial para establecer una base para el mejor desempeño en términos ambientales y este desempeño varía según el tipo de propiedad (pública o privada). Los resultados también indicaron que el alcance de las acciones ambientales se correlaciona con la capacidad de resiliencia organizativa y con los motivadores que impulsan a los hospitales a realizar las acciones de sostenibilidad. Se proponen dos modelos conceptuales para ilustrar estas conclusiones y proporcionar las bases para futuras investigaciones.
\end{abstract}

Palabras clave: Hospital. Sostenibilidad. Medio ambiente. Resiliencia organizativa. Acciones.

Article received on March 31, 2016 and accepted on June 2, 2017

Original Version

DOI: http://dx.doi.org/10.1590/1679-395160285 


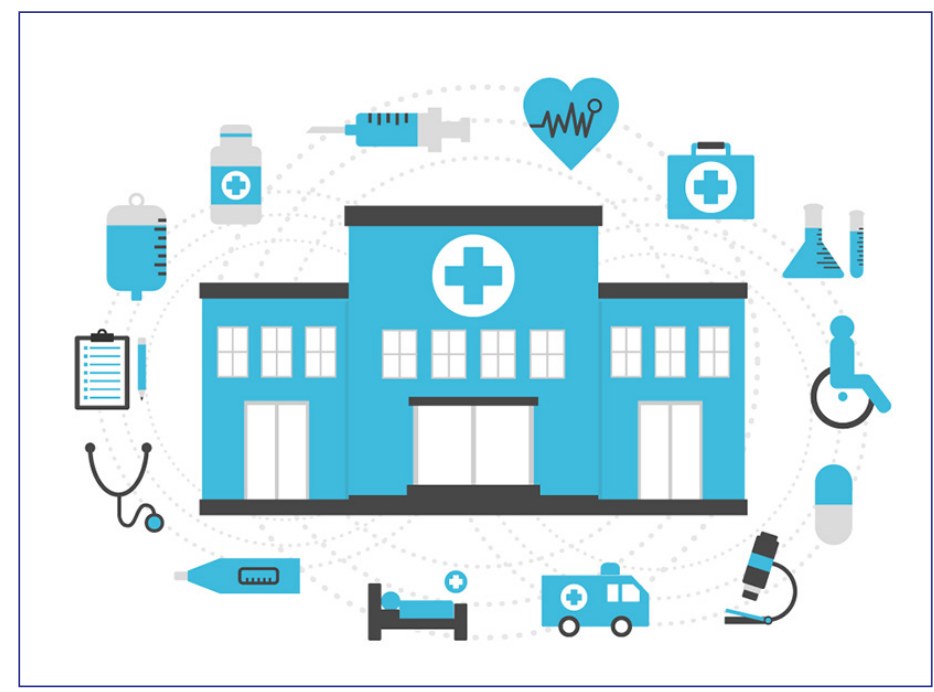

\section{INTRODUCTION}

Environmental sustainability has shown to be of growing interest among academia, governments, organizations and society as a whole. It has become widely accepted that direct and indirect human interference are having profound impacts on the balance of ecosystems around the world, thus triggering full-scale global climate change. According to environmental reports, these changes pose a real threat to countries all over the world when it comes to providing basic human amenities to their population, such as food provisions and safety from natural hazards. Climate is becoming increasingly extreme, leading to accelerated desertification in some places while other areas suffer from excess precipitation or drought. It has been suggested that these changes are caused by direct or indirect human activity.

Sustainable development aims at tackling the challenge of how to provide social and economic advancement without negative outcome to the environment. The most common definition of sustainable development was coined at the World Commission on Environment and Development convention in 1987: "Sustainable development is the kind of development that meets the needs of the present without compromising the ability of future generations to meet their own needs" (REPORT..., 2012), although the resources required to fulfill current and future needs could, in theory, be substituted for others. However, Ekins (2011) argues that it is not possible to determine if a given resource, exhausted by one generation, could be substituted in the future by another one since this availability is undermined by several uncertainties.

On a more singular level, a parallel can be drawn between sustainability and medicine as a practice. For over a century of social and economic improvements, medical treatment and improved pharmaceuticals have increased human life expectancy by several decades. In fact, a common mission statement of hospitals and healthcare organizations is to preserve life and treat diseases. Thus, there seems to be a logical and ethical duty in medicine to avoid externalities that might work against its ultimate goal.

Unlike a hospital's mission to sustain life, the equipment and installations used to do so commonly end up having a negative effect on human health if environmental externalities are taken into account (ULH $\varnothing$ I and ULH $\varnothing I, 2009$ ). Although a strong cause-effect relationship is not possible to be determined, researchers are arguing that the medical sector has the ethical obligation to follow a "do no harm" philosophy to also overcome their challenges through forms of resilience. Thus, normally, as an empirical point of view, when hospital managers are facing difficulties (financially, organizationally) to adapt to changes, environmental responsibility programs are put in a second plane. Here, we can suggest that resilience

Image source: Designed by Zirconicusso / Freepik. 
could be seen as a dynamic process whose outcome is the successful adaptation and transformation of the individual. Therefore, organizational resilience would personified in the resilience of individuals, specifically in the managers whose behaviour, individual and collective, help or hinder organizational resilience, highlighting the revelation as to how resilience influence the decision-making process (GOLDSCHMIDT, 2015).

The objective of this paper is to investigate what motivates hospital managers to adopt environmental responsibility programs and to identify the actions implemented by them. Thus, the three main research questions are: (1) Why do hospital managers adopt environmental responsibility programs? (2) What are the critical actions these managers take regarding environmental sustainability? and (3) Concerning organization resilience, how hospital managers can use environmental actions to overcome their new challenges?

Even though there is an alignment between the field of medicine, psychology and environmental sustainability, adherence to environmental sustainability practices are incipient, and academic research is even scarcer. Therefore, this research aims to strengthen the theoretical foundation to bring these fields closer together and to advance the academic research regarding environmental management in the healthcare sector.

\section{CONCEPTUAL FRAMEWORK}

\section{Motivating factors to adopt environmental responsibility program}

Corporate sustainability is nowadays a business imperative as regulators require, investors demand, and corporations continue to disclose sustainability information (REZAEE, 2017). In this context, social and environmental sustainability has made significant advancement over the last decades and has being integrated into the business culture (PORTER; KRAMER, 2011). However, according to Porter and Kramer (2011), these advancements have been largely pushed upon the organizations by external sources of pressure, like tighter regulation by governments and unexpected public pressure. These authors argue that most organizations view the effort towards social and environmental responsibility as a defense mechanism instead of developing an approach that makes more sense with the organizations strategy as a whole. Corroborating to this understanding, the results of a systematic review carried out by Dienes, Sassen and Fischer (2016) indicates that companies only report on their sustainability activities if there is an economic benefit derived from improved reputation, reduced capital costs or alleviated public pressure.

Dubois and Dubois (2012) defend that there are three context drivers that pressure organizations toward environmental initiatives: insufficient natural resources; increasing pressures from stakeholder groups - regulators, investors, employees, and consumers; and transparency - concern about the public information regarding the impact of organizations on the natural environment. In turn, research conducted by Renukappa, Egbu, Akintoye et al. (2013) indicated that there are five drivers to embedding sustainability initiatives: reducing operating costs; protecting or enhancing organizational reputation - increase competitiveness and market share; stakeholders' pressure; government regulation/legislation; and top management commitment.

In a simpler way, Paulraj (2009) asserts that there are three main drivers regarding the adoption of environmental sustainability programs: Regulation, Competition and Ethics. The regulative dimension is arguably the most obvious of these three because it can exert a coercive power that will bring organizations to adopt environmental practices. The regulator, in most cases the state, can also assume the position of facilitating the adoption of environmental sustainable practice by providing the necessary support to drive organizations in this direction. Competition is another important driver because some companies believe that environmental sustainability programs will enhance their competitive positioning. The third dimension refers to ethical issues and companies take responsibility for the environment because they believe that this is the right thing to do.

Understanding the drivers to adopt environmental initiatives is important because the environmental performance reflects how effectively a company addresses its environmental challenges in leaving a better environment for future generations (REZAEE, 2017). In a recent study, Zadeh, Xuan and Shepley (2016) suggested that sustainability in healthcare practice means focusing on the broad meaning of sustainability by encompassing environmental, social, economic and health-related aspects. In a recent research, Blass, Costa, Lima et al. (2016) propose a framework and a process to evaluate the environmental performance at 
Brazilian hospitals. According to them, formalization of performance measures across healthcare organizations is still scarce and there is a lack of guidelines on the development and selection of performance indicators. So, they conclude that measures that can raise awareness, continuous improvement and innovation in healthcare organizational processes are required.

\section{ENVIRONMENTAL CLASSIFICATION MODELS}

With regard to the models that describe and classify environmental sustainability strategies of organizations, while there are several additional models (for a comprehensive list until 2000 please refer to Kolk and Mauser, 2002), we selected six models because they present different approaches which span the last two decades and can all be clearly linked to the three main motivational factors presented by Paulraj (2009). The chosen models also complement each other and thus have become the basis for the research framework, as well as the interview guide used in the field research.

Hunt and Auster (1990) present a continuum model which categorizes organizations environmental programs along five stages: beginner; fire fighter; concerned citizen; pragmatist; and proactivist. The three most salient criteria that differentiate one stage from another are the degree to which the program reduced environmental risk, the commitment of the organization and the design of the environmental program. According to these authors there is a natural progression from one stage to the next over this continuum, and the specificities of each sector should be taken in consideration when an environmental management program is being designed and implemented by an organization.

According to Hass (1996), there are two main types of classification models of environmental strategies: stage models, which classify a given strategy in a continuum scale; and categorical models, in which a strategy is placed into a category according to its characteristics. In the later model organizations can move from any given classification to another while the continuum model poise that an organization evolves according to a predetermined path. This author argues that companies that have a developed and well-structured environmental management system have clear and formal politics, as well as leaders support.

Vastag, Kerekes and Rondinelli (1996) propose an environmental strategy model based on two dimensions - endogenous risk and exogenous risk. According to them, the tendency of ever more strict regulation regarding environmental conducts has risen the pressure on organizations to implement comprehensive environmental management programs. However, they argue that the implementation of standardized actions is not ideal because each organization and sector has particularities that should be taken under consideration during the design and implementation of an environmental management program. The proposed classification model is based on mapping the internal and external risks to which the organization is exposed, and has four categories: proactive; strategic; reactive; and crisis preventive. The authors define environmental risk as the probability that exists of a negative externality produced by the operation of that business.

Similarly to Hass (1996), Winn and Angel (2000) establish dimensions dealing with the implementation of the environmental management program and the formal commitment of corporate policies. Both models point to the existence of situations where there is an imbalance between the formal politics and the actual implementation of the pretended actions. The four categories proposed have been named "Deliberate Reactive", "Unrealized", "Emergent Active" and "Deliberate Proactive". The authors based their research on the literature of corporate social performance, organizational strategy and previous models of environmental strategy to determine which are the most important and relevant dimensions in the adoption of a corporate environmental strategy.

Abreu (2009) tries to develop a model of environmental classification that can be used in both developing and developed economies and that is applicable to a wide range of sectors. The proposed model categorizes organizations according to the environmental pressures they are exposed to and the institutional conduct of these organizations. The categories are: innovator; defender; sleeper; reactor. According to the author, the environmental pressures have roots in risk of environmental damage, regulation and the actual enforcement of this regulation and several stakeholders' demands. Companies that operate in economic sectors with high regulation and enforcement, with and active body of stakeholders that remain vigilant to environmental issues and exercising activities that have high externalities are classified as having high environmental pressure. On the other hand, companies that operate in a sector with low regulation, with no vigilant stakeholders and producing limited externalities from their operations are classified as having low environmental pressure. 


\section{Environmental sustainability and organizational resilience}

The research of Vasconcelos, Cyrino, D'Oliveira et al. (2015) aims to relate the concept of sustainable innovative organization to the concept of organizational resilience. In order to do this, they carried out a study at the human resources department of EBE S.A., a Brazilian energy company. A theoretical review was conducted about the concepts of resource-based vision, core competencies, dynamic capabilities, strategic human resources management, learning organization, organizational resilience, sustainable innovative organization, and also about the human resources management practices of EBE S.A. that contribute to make the company a Resilient Sustainable Innovative Organization. For them, the practices of strategic management of the Corporate HR contributed to create an environment conducive to innovation and make the EBE S.A. an innovative organization. In order words, it is possible through a concise organizational resilience improve ways of continuous innovation and sustainability at high standards of economic, social and environmental management.

In turn, the work of Goldschmidt (2015) is concerned about what organizational managers understand about resilience, a theme that is strong related to sustainable innovation among organizations. The author aims to identify exclusively the discursive practice, figures of speech, intertextuality, background themes and relate them to the elements of academic discourse corpus, which allowed the establishment of analytical categories of: human resilience and organizational resilience. According to Goldschmidt, the influence of resilience in the decision making process signals a common denominator on which academic research can break, allowing the development of epistemological propositions, methodological and praxeological that increase the chances of access by individuals and organizations, a repertoire of productive responses to adversity.

The models presented here show very clearly that there is no consensus on which criteria and dimensions are most adequate to classify an organizations approach to environmental sustainability programs. Nontheless, the selected models have commonalities and paralels which, when taken together and suplemented with the notion of three main drivers of sustainability from Paulraj (2009), offer a strong basis for the exploratory research carried out in this paper. Figure 1 exemplify how the different models connect with one another.

Figure 1

Visual map of models and criteria

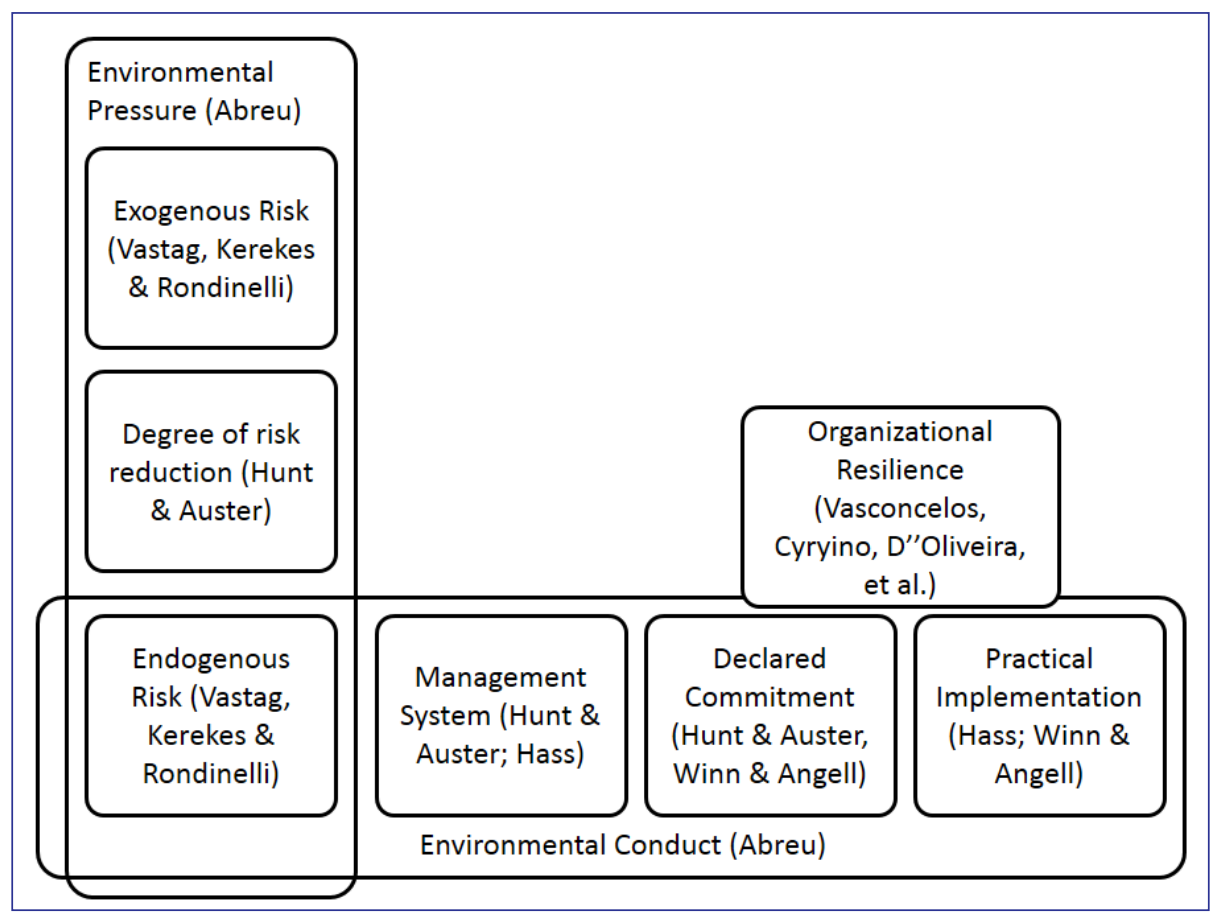

Source: Elaborated by the authors. 
In Figure 1, two main axes are drawn from Abreu's (2009) model: Environmental Pressures, which can be both internal and external, and Environmental Conduct which represents organization's internal processes and procedures. Vastag, Kerekes and Rondinelli's (1996) exogenous risk and Hunt and Auster's (1990) degree of risk reduction criteria have commonalities with Abreu's Environmental Pressure dimension. Additionally, Vastag, Kerekes and Rondinelli's (1996) endogenous risk provide a bridge between Abreu's dimensions.

Also, the concept of organizational resilience proposed by Vasconcelos, Cyrino, D'Oliveira et al. (2015) highlights a concise dialogue with the works of Hunt and Auster (1990) and Winn and Angell (2000). For them, organizational resilience is the organizational ability to handle with recovery, rapid adaptation and effective change of disruptive events produced by real innovation in a virtuous circle, quickly reaching productive state for growth and development at an organizational level more complex. From this concept, in addition to Vastag, Kerekes and Rondinelli's (1996) endogenous risk and Abreu's (2009) environmental conduct, it is possible to align three other main dimensions in the internal axis of Figure 1: the environmental management system (HUNT and AUSTER, 1990; HASS, 1996), the declared commitment of the organization (HUNT and AUSTER, 1990; WINN and ANGELL, 2000) and the practical implementation of the environmental programs (HASS, 1996; WINN; ANGELL, 2000). All these models provide insight to actions and drivers that lead management to adopt environmental management programs in their organizations.

\section{METHODOLOGY}

Despite the fact that there are several initiatives in the field of environmental management in hospital operations, the amount of academic research addressing the issue is limited, thus justifying research seeking to answer questions of "how" and "why" these managerial movements occur (YIN, 2014). Eisenhardt (1989) contributes to this view, arguing that a case study approach is most appropriate in the early stages of a research topic.

Unlike quantitative research, which focuses on statistical sampling to achieve a representative group of subjects in the study, the case study methodology follows a theoretical sampling, aiming to enrich the study as a whole (EISENHARDT, 1989; YIN, 2014). Yin (2014) argues that in a multiple case study, the selection should be made in order to achieve a literal replication, in which each additional case leads to similar outcomes, or a theoretical replication, in which case the researcher expects different outcomes due to predictable reasons. The latter method was chosen and selection of the cases is detailed below.

Because hospital operations vary according to the type, intensity and quality of medical treatment, it was determined that only hospitals which provided high quality services would be taken into consideration for this research. To fulfill this purpose, the Joint Commission International (JCl) hospital accreditation was selected as a qualifying factor. Interviews that were conducted before the current case studies with two managers working for one of the biggest health maintenance organizations (HMO) in Brazil showed that such a criterion would level the cases in terms of quality of medical services provided by the organizations. It was further determined that the hospitals should be located in Rio de Janeiro or São Paulo due to travel and access limitations. Sixteen hospitals met these criteria and were contacted through telephone and email. Two private hospitals and two public hospitals responded positively to the research proposal. The characteristics of selected hospitals are presented in Table 1. 
Table 1

Characteristics of selected hospitals for the case study

\begin{tabular}{cccccccc}
\hline Hospital & Ownership & Location & specialization & $\mathrm{m}^{2}$ & Beds & Employees & $\mathrm{JCl}$ Accr. Yr. \\
\hline HA & Private Not-for-Profit & São Paulo & General & 135000 & 650 & 6080 & 1999 \\
\hline HB & $\begin{array}{c}\text { Private For-Profit } \\
\text { HMO }\end{array}$ & São Paulo & Cardiology & 8100 & 93 & 440 & 2010 \\
\hline HC & Public Federal & $\begin{array}{c}\text { Rio de } \\
\text { Janeiro }\end{array}$ & Orthopedics & 70000 & 321 & 4700 & 2006 \\
\hline HD & Public Federal & $\begin{array}{c}\text { Rio de } \\
\text { Janeiro }\end{array}$ & Oncology & 6200 & 87 & 490 & 2008 \\
\hline
\end{tabular}

Source: Elaborated by the authors.

Prior to field research, two interviews were conducted with managers of a leading HMO provider to gain knowledge on the characteristics of the sectors, validate some assumptions and check if the interview guide was appropriate. Minor changes were carried out in the interview protocol after these initial conversations.

Thirteen semi-structured interviews were carried out during July 2014 and between March and May 2015 with 2-5 managers from each hospital. Table 2 presents the profile of the interviewees.

Table 2

\section{Profile of the interviewees}

\begin{tabular}{ccccc}
\hline Interviewee & Hospital & $\begin{array}{c}\text { Years at the } \\
\text { Company }\end{array}$ & Age & Position \\
\hline A1 & HA & 4 & 38 & Director \\
\hline A2 & HA & 6 & 65 & Manager \\
\hline B1 & HB & 5 & 29 & Manager \\
\hline B2 & HB & 3 & 30 & Technician (susbtituting for \\
B3 & HB & 7 & 51 & manager) \\
\hline B4 & HB & 6 & 50 & Director \\
\hline B5 & HB & 6 & 40 & Coordinator \\
\hline C1 & HC & 7 & 41 & Manager \\
\hline C2 & HC & 9 & 43 & Manager \\
\hline C3 & HC & 8 & 43 & Coordinator \\
\hline D1 & HD & 10 & 36 & Director \\
\hline D2 & HD & 10 & 36 & Director \\
\hline D3 & HD & 27 & 60 &
\end{tabular}

Source: Elaborated by the authors.

The interviews were recorded and transcribed by the authors in order to identify possible passages that met with the research framework. Each section that presented relevant information to the research theme or which could be clearly linked to a proposition presented in the framework was marked and copied to a table. This table identifies the author of the remark, which organization he or she belongs to, which pages of the transcription the remark is on and which proposition of the 
framework it is linked to. This structured approach is intended to avoid the common pitfall of qualitative research of being overly exposed to subjective interpretation of the authors. Also, this analysis enabled the author to filter the necessary evidence out of the interviews, thereby providing the base for subsequent analysis. A total of 335 sections were extracted from the transcriptions into the analysis tables.

As secondary data, the researchers' observation during the interview visits was considerate, as well as documentation provided by the organizations or published on their websites. The use of multiple data sources provides additional credibility and reduces bias (EISENHARDT, 1989; YIN, 2014).

\section{RESULTS AND DISCUSSION}

\section{What motivates hospital managers to adopt environmental responsibility programs?}

Evidence supporting the three driver categories presented by Paulraj (2009) was found during the research. Table 3 shows in which cases supporting evidence was found for each statement of the research framework. While in some cases there were isolated mentions that do support one of the propositions, Table 3 only accounts for the cases where the issue was addressed by more than one interviewee and statements were consistent across the interview itself and corroborated by other interviewees.

Table 3

Summary of findings according to research framework - DRIVERS

\begin{tabular}{|c|c|c|c|c|}
\hline \multirow[b]{2}{*}{ Framework Proposition: Competitive Drivers } & \multicolumn{4}{|c|}{ Hospital } \\
\hline & HA & HB & $\mathrm{HC}$ & HD \\
\hline $\begin{array}{l}\text { Environmental responsibility programs have positive effect on the economic and } \\
\text { competitive performance, ensuring short and long term benefits. }\end{array}$ & $x$ & $\mathrm{x}$ & $x$ & $x$ \\
\hline \multicolumn{5}{|l|}{ Environmental programs are key factor to acquire new customers. } \\
\hline Framework Proposition: Ethical Drivers & HA & HB & $\mathrm{HC}$ & HD \\
\hline $\begin{array}{l}\text { Environmental sustainability is a challenge for all and we have to do our part because it's } \\
\text { the right thing to be done. }\end{array}$ & $x$ & & & \\
\hline $\begin{array}{l}\text { Personal beliefs of top management is a key factor in the adoption of environmental } \\
\text { responsibility. }\end{array}$ & $x$ & $x$ & & \\
\hline Framework Proposition: Regulator Drivers & $\mathrm{HA}$ & HB & $\mathrm{HC}$ & HD \\
\hline $\begin{array}{l}\text { We are interested in being prepared for future environmental regulation to avoid problems } \\
\qquad \text { when they come into practice. }\end{array}$ & $x$ & & & \\
\hline The environmental program aims at fulfilling environmental regulation and avoid sanctions. & & & $x$ & $x$ \\
\hline
\end{tabular}

Source: Elaborated by the authors.

The first competitive driver was present in all hospitals in the form of concerns regarding cost-saving measures, as derived in the research framework of Paulraj (2009), Renukappa, Egbu, Akintoye et al. (2013) and Vastag, Kerkeres and Rondinelli (1996). While this research effort had no quantitative approach to measure relative importance within and across cases, a clear impression gained from the interviews is that the cost-saving driver is more pressing in private institutions, which depend on revenue to sustain their operations. The second competitive driver, based on contributions from Paulraj (2009) and Abreu (2009), which addresses the acquisition of new clients based on differentiation from competition using environmental initiatives, found no reliable evidence in the research process. 
The first ethical driver was based upon Paulraj (2009), Vastag, Kerkeres and Rondinelli (1996) and Winn and Angell (2000), regarding the moral duty of organizations to the sustainability challenge. Clear evidence for this driver was found only in HA, which has a strong connection to an ethnic group. The fact that this hospital has a strong stakeholder group, which holds common values within it, suggests the possibility of transferring those values to the organization. For the other institutions, there was no evidence of a similar compact and homogeneous stakeholder group that could infuse the organization with such values. An overarching stakeholder group can be associated as a whole in this case. According to the interviewees, general concern for environmental matters is still very low in Brazil. The second ethical driver was based on Paulraj (2009), Renukappa, Egbu, Akintoye et al. (2013) and Vastag, Kerkeres and Rondinelli (1996), regarding top management support for the environmental initiatives. In all cases, hospital managers expressed genuine concern and beliefs in favor to environmental management as an important task. However, the interviews conducted in the public hospitals point to the fact that those personal beliefs are hindered by the governance structure and culture of these organizations.

Regulation driver has been proposed in a futureoriented and presentoriented fashion. The notion of adopting environmental practices as a pre-emptive action against future regulation has been proposed by Winn and Angell (2000). Only in the interviews from HA there was a consistent futureoriented approach to regulation. The annual sustainability report has also a future oriented emphasis. The second regulatory driver was derived from Paulraj (2009), Dubois and Dubois (2012), Renukappa, Egbu, Akintoye et al. (2013), Vastag, Kerkeres and Rondinelli (1996) and Abreu (2009) and addressed current regulation as a driver. The interviews from both private hospitals showed regulation to be the main driver for the actions that they consider to be linked to environmental responsibility.

A visual representation that hopefully will lead to further research efforts and that can serve as a heuristic model for both practitioners and academics is proposed in Figure 2. An underlying initial problem is the fact that there are no consistent and widespread environmental performance data on hospitals, as pointed out by Blass, Costa, Lima et al. (2016). Figure 2 does, however, encompass the findings from the interviews.

Figure 2

\section{Proposed Motivator/Performance Model}

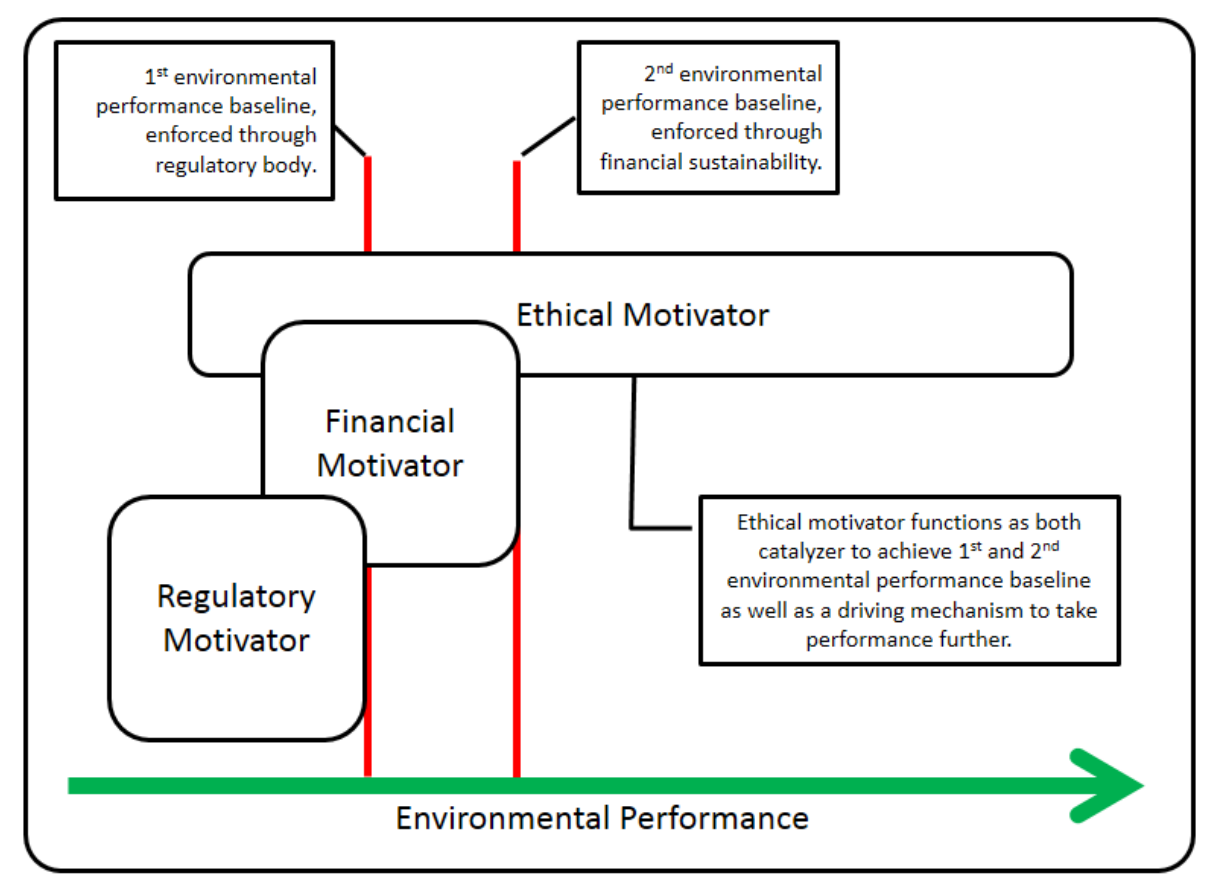

Source: Elaborated by the authors. 
For the hospitals analyzed, the regulatory motivator is the first performance baseline and is heavily dependent on the state. The competitive motivator represents the second baseline and showed to be limited to financial concerns, but private and public hospitals might contrast in terms of the importance of this performance baseline. Lastly, if society as a whole does not approve a given ethical posture, the organization will then face a legitimacy vacuum and/or suffer from a lack of customers. Thus, ethical motivator can be seen as a catalyzer to achieve the previous baselines and can be a mechanism to take performance further.

\section{What are the critical actions hospital managers are taking regarding environmental sustainability?}

Besides the motivational drivers, the literature also provided a series of propositions and questions, which were summarized into action statements against which the interviews and secondary data were compared. This, as well as statements about the environmental actions that the hospitals performed, were the basis to answer the second research question. From the research framework, we have several statements linked to the competitive, ethical and regulation drivers. An interesting point that became clear during the research effort is the existence of disequilibrium between what is happening and the intent of some interviewees. Table 4 shows in which cases supporting evidence was found for each statement of the research framework.

Table 4

\section{Summary of findings according to research framework - ACTIONS}

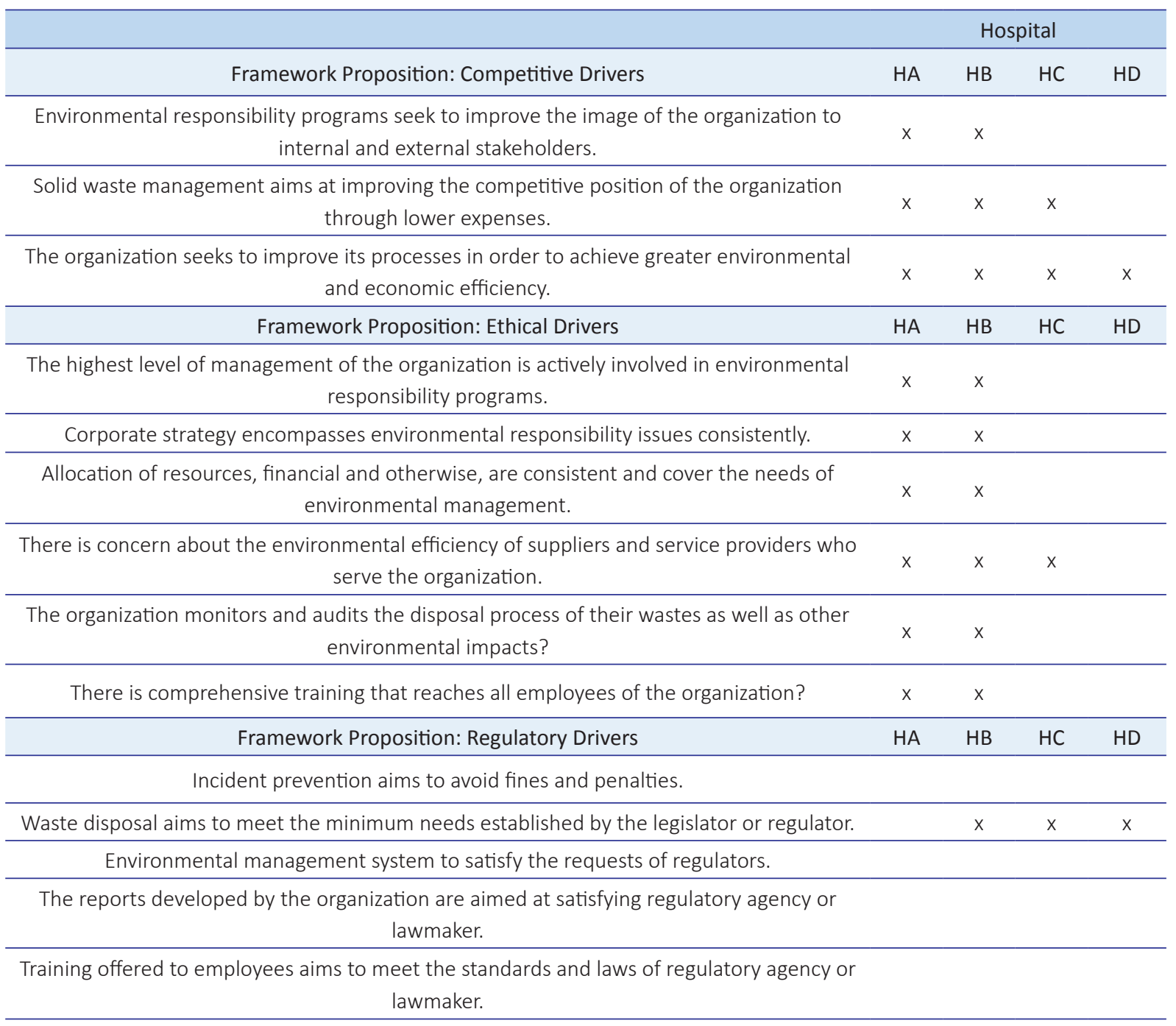

Source: Elaborated by the authors. 
The first two actions related to the competitive drivers were based on statements in Vastag, Kerkeres and Rondinelli (1996), Abreu (2009) and Dubois and Dubois (2012). The first action - improving positive perception of stakeholders - was present in both private hospitals. The main targets of these efforts according to the interviewees were the staff themselves, followed by patients. In HC, this point was not consistently observed, but the interviewees cited the fact that although the hospital seeks to be a reference for its staff and patients, such initiatives are still incipient. The second action addresses economic benefits, which can stem from improved solid waste management. This was corroborated in most cases and only the hospital that had the leastdeveloped environmental practices did not show strong beliefs on the part of managers that moreadvanced solid waste management practices can save money. In all cases, the issue was addressed more from the medical safety and financial standpoint than from the environmental standpoint. So, the interviews suggest that, in this case, environmental benefits are a welcome side effect and not a primary objective. The third action relates to operational improvements, which seek environmental and economic benefits. This statement was based on Vastag, Kerkeres and Rondinelli (1996), Winn and Angell (2000), Abreu (2009) and Renukappa, Egbu, Akintoye et al. (2013). The action was encountered in all hospitals. In all cases, the economic factor was shown to be paramount with environmental benefits, once again, being deemed a welcome side effect.

Actions related to the ethical drivers showed the greatest disparity between private and public hospitals. The first and second actions can be taken together in this analysis, i.e., top-level management's involvement with the environmental issues (HUNT; AUSTER, 1990; HASS, 1996; VASTAG, KEREKES and RONDINELLI, 1996; WINN and ANGELL, 2000; RENUKAPPA, EGBU, AKINTOVE et al., 2013), and whether formal corporate strategy encompasses environmental issues (HASS, 1996; VASTAG, KEREKES and RONDINELLI, 1996; WINN and ANGELL, 2000; PORTER and KRAMER, 2011). This was only found to be the case in the private hospitals. Governance and power structure of the public institutions, as well as other pressing issues have been cited as impediments in these cases. The interviews in these cases also suggest that Brazilian society does not press for environmental accountability in the public healthcare sector, given the fact that the public hospitals still fail to provide medical services to meet demand. In HC, however, some incipient actions suggest the scenario might be changing. Interviewees mentioned that grass-root initiatives from the waste management team led higher management to determine the establishment of a working team to institutionalize more sustainable logistics processes for the hospital.

The third action - the allocation of financial and other resources to the environmental issue - is based on Hunt and Auster (1990) and Abreu (2009). In both private hospitals the interviewees said they were satisfied with the amounts of resources available. In HA, which has the highest investments, the notion was that it would not be appropriate to invest more before having a consolidated environmental culture amongst staff. Public hospitals, on the other hand, have shown a consistent lack of allocation of resources to environmental initiatives. Governance, power structure and the high demand for treatment have been suggested as reasons for the lack of resources committed to the issue.

The fourth action dealt with environmental concerns of the hospital towards their suppliers and service providers (VASTAG, KEREKES and RONDINELLI, 1996; WINN and ANGELL, 2000; ABREU, 2009; 2011). Again, we have seen a consistent approach from the private hospitals, partially driven by the fact that both have ISO14.001 certification and it does suggest austere contracting and procurement policies. $\mathrm{HC}$ also demonstrated initiatives concerning procurement, in sum, a combination of regulation mandating environmental attributes in procurement processes and the personal efforts of the waste management team, which had become the focal point for issues concerning environmental responsibility even without formal remit or the required resources. The fifth action - the monitoring of environmental impacts - is based on Hunt and Auster (1990), Vastag, Kerekes and Rondinelli (1996) and Abreu (2009). Here again, private hospitals excelled in relation to the public ones. One fact that became clear during the research process is that both private hospitals have information systems that are more advanced and enable the ability to store and retrieve environmental information. The public institutions, in turn, seemed to resort to less advanced information technology and data collection and information workflow was less sophisticated. HC, again, showed incipient actions to increase data availability to enhance its environmental performance. The interviews suggested that in this case it was the personal commitment on the part of the waste management team that enabled such advances.

The last action related to ethical driver is comprehensive training by environmental management for all employees (VASTAG, KEREKES and RONDINELLI, 1996; ABREU, 2009; 2011). The private hospitals showed a more structured approach to this matter. In all cases, managers stated that the approach of the general population to environmental responsibility is deficient and that employees need to receive comprehensive training and education to assimilate and internalize environmental management concepts. It was also pointed out several times that medical and nurses are not exposed to the basics of environmental 
responsibility during their academic training, even though they might be dealing with highly impacting materials. Although comprehensive training for all employees are not present in the public institutions, the interviewees from HC asserted that there are incipient movements to establish a more comprehensive environmental training and in HD employees responsible for training have been on a personal crusade to raise awareness surrounding the issue. In both cases, it can be stated that, despite the genuine concern, resources are lacking to adopt a comprehensive environmental training for all employees.

Finally, of the five actions related to regulation, only one was consistently manifest in the interviews: waste disposal (VASTAG, KEREKES and RONDINELLI, 1996), including sewage. The management of solid waste as established by regulation was presented as an environmental initiative at $\mathrm{HB}, \mathrm{HC}$ and $\mathrm{HD}$ and was cited as the most important environmental activity in both public hospitals. Environmental incident prevention to comply with regulation (VASTAG, KEREKES and RONDINELLI, 1996), environmental management system (HUNT and AUSTER, 1990; VASTAG, KEREKES and RONDINELLI, 1996; ABREU, 2009), environmental reporting (HUNT and AUSTER, 1990; HASS, 1996; ABREU, 2009) and minimum environmental training to comply with regulation (VASTAG, KEREKES and RONDINELLI, 1996; ABREU, 2009) did not find support in the interviews.

Besides the actions already mentioned, some findings appeared consistently across interviews. One is the notion by the managers interviewed of a clear link between negative externalities and human health condition. This was supported by interviewees from HA, HB and HC. Another finding, present in $\mathrm{HA}$ and HB, is the use of self-regulative mechanisms for environmental matters, such as the adoption of external audits and certification.

Briefly, regarding the actual implementation of environmental practices, the results of this research indicate that there is a natural hierarchy of environmental priorities in hospital management, starting from the outputs and visible direct externalities of such institutions. The first priority concerns to correct waste handling, followed by waste reduction and then resource utilization efficiency. More elaborate strategies, involving suppliers to develop moresustainable logistics and consumables and active lobbying for morecomprehensive regulation on the issue, are of a higher nature in this hierarchy. These results are summarized in the proposed environment actions model presented in Figure 3.

Figure 3

\section{Proposed Environmental Actions Model}

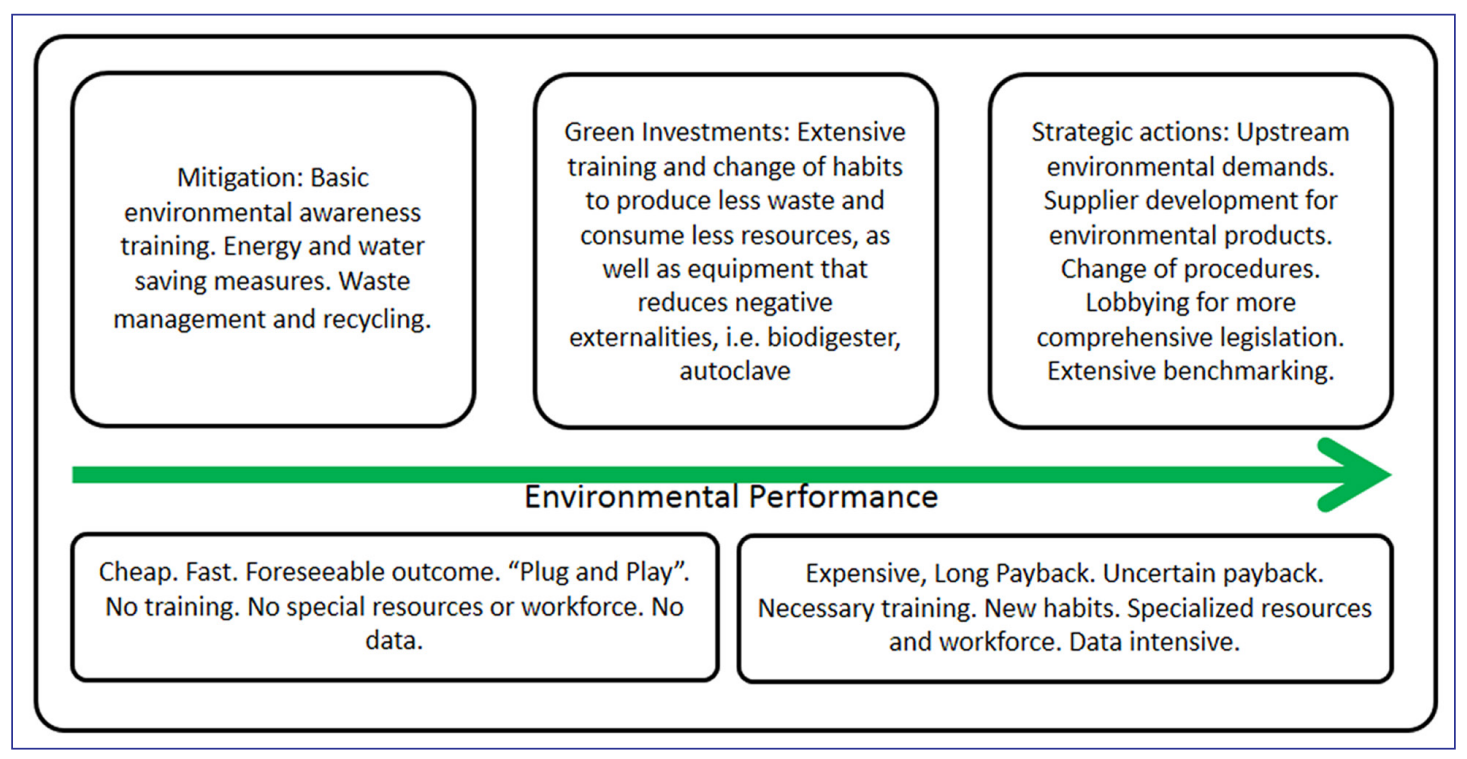

Source: Elaborated by the authors.

While there is certainly no predetermined path to be followed, the interviews demonstrate consistent patterns across hospitals in the implementations steps of environmental practices. Specifically, environmental concerns start with waste management, energy and water consumption. Basic energy and water saving methods (such as LED bulbs and twostage flushing) can be 
copied from other sectors' experiences without extensive or specialized knowledge. Basic recycling policies are also easy and fast to implement and reductions in infectious waste can be reasonably implemented without excessive financial resources. We can call this first step as "Mitigation".

A further stage of actions, called "Green Investment", involves greater financial/resource investment, extensive training and advanced equipment. Significant processes and procedures changes even as hiring a specialized workforce can be required. A third stage, "Strategic Actions", where the organizational resilience cohabits, involves actions that deeply modify the services provided and the relationship between hospitals, their suppliers and regulators to avoid negative externalities. Examples include lobbying for regulation that incentivizes environmental innovation and practices and engaging suppliers in the effort of producing less harmful and environment-impacting medical supplies. Common characteristics of such actions include the change of habits, more complexity in dealing with external parties, and the intensive use of data for benchmarking.

\section{How hospital managers can use environmental actions to overcome their new challenges?}

Evidence from the interviews showed that in most cases the environmental benefit of the environmental actions is a welcome "side effect" of financial sound practices, mainly in relation to organization resilience, as the hospital managers express that these actions could help to overcome their financial challenges. The environmental practices are not seen as competitive differentiation factor for hospitals. While the denomination used throughout this paper has been Paulraj's (2009) "competitive driver", the findings suggest that a more appropriate name would be "financial driver".

According to the managers interviewed, the fact that healthcare organizations are showing increasing environmental impacts indicates that there is a general need for more strategic environmental actions in this sector if externalities are to be kept at current or lower levels in the future. As advocated by Vasconcelos, Cyrino, D'Oliveira et al. (2015) and Zadeh, Xuan and Shepley (2016), the strategic sustainability actions and the organizational resilience by the hospital managers might involve a more complex set of actors in the value chain of the whole sector and focus on the broad meaning of sustainability by encompassing environmental, social, economic and health-related aspects.

\section{CONCLUSION}

This paper investigated what motivates hospital managers to adopt environmental responsibility programs and the actions implemented by them. A multiple case study methodology was chosen given the early stages of academic research on environmental responsibility in the healthcare sector and the type of questions that were proposed.

The findings show that the three main motivating dimensions proposed by Paulraj (2009) are present in the adoption of environmental responsibility practices in the hospitals analyzed. The interviews and analysis carried out for this research point to the fact that the ownership type and governance structure of those organizations determine which motivating dimensions will have greater influence over managers' decision making processes.

In relation to the competitive drivers, the managers interviewed showed concern regarding cost-saving measures and we could call this dimension as "financial driver". Ethical drivers were present only in the private institutions analyzed. This may be because private institutions have the necessary autonomy and resources required to implement environmental practices in accordance with the stakeholders who wield influence on management Regulation driver, on the other hand, has shown to be of great importance for the public hospital managers. Given the governance and power structure of these institutions, the topdown mandates in the form of regulations and norms have shown to be the primary driver for consistent adoption of environmental practices. At the same time, regulation results in low prioritization and effectiveness of such measures. While the private hospitals analyzed appeared to be less motivated by regulation than by other drivers (financial and ethical), it must be noted that both hospitals are considered to have high quality services, which is not the case for many private hospitals in Brazil. It is likely that private hospitals that do not have access to the resources available to those in the cases investigated will be more affected by regulation and financial motivators than by ethical motivators. 
Regarding the actions implemented by the hospitals investigated, the Environmental Actions Model proposed here recognizes that there is a natural tendency of hospital managers to pluck the "low hanging" opportunities regarding environmental actions, that is, to engage in environmental actions that are easy to implement without further difficulty or need for innovation. However, assuming that future regulatory and market changes will drive the environmental performance baseline forward, environmental actions implemented in hospitals will need to move from the mitigating to the strategic pole of the proposed model to keep up with future requirements. Such a move will require tailored actions, forms of organization resilience and new strategies for the sector.

Finally, based on the hospitals investigated, we could say that environmental management is still in its early stages, and that regulation on the matter is both very flexible in terms of environmental performance and too strict to allow for environmental innovation in this sector.

Despite its contributions, some limitations of this research are worth mentioning. As with all research methods, the case study methodologies have its limitations. The first is the possible bias from the researcher during the gathering and analysis processes. The difficulty in distinguishing between variables and events during the research contributes to this fact. Further on, the interviewees also introduce their share of bias to the research given the fact that their answers are based on personal believes and perceptions which by definition are subjective. A second limitation of case studies is that they offer little basis for scientific generalization. Since the objective of this article is not to provide an overarching theory, but rather provide a very specific and incipient view on the subject, there is no aspiration of providing results that can be generalized.

The dearth of academic research in this specific sector requires further efforts to advance from the proposed conceptual models to quantitative research and management tools that can assist managers to implement environmental sustainability actions in their hospitals. Since this is an exploratory study, our main contribution here is to propose models that could be tested in future quantitative research 


\section{REFERENCES}

ABREU, M. C. S. Effects of Environmental Pressures on Company Sustainability Strategies: An Interview Study among Brazilian Manufacturing Firms. International Journal of Management, v. 28, n. 3, p. 909-926, 2011.

ABREU, M. C. S. How to define an environmental policy to improve corporate sustainability in developing countries. Business Strategy and the Environment, v. 18, n. 8, p. 542-556 2009.

BLASS, A. et al. Measuring environmental performance in hospitals: a framework and process. Measuring Business Excellence, v. 20, n. 2, p. 52-64, 2016.

DIENES, D.; SASSEN, R.; FISCHER, J. What are the drivers of sustainability reporting? A systematic review. Management and Policy Journal, v. 7, n. 2, p. 154-189, 2016.

DUBOIS, C.; DUBOIS, D. Strategic HRM as social design for environmental sustainability in organization. Human Resource Management, Human Resource Management, v. 51, n. 6, p. 799-826, 2012.

EISENHARDT, K. M. Building Theories from Case Study Research. Academy of Management Review, v. 14, n. 4, p. 532-550, 1989.

EKINS, P. Environmental sustainability: From environmental valuation to the sustainability gap. Progress in Physical Geography, v. 35, n. 5, p. 629-651, 2011.

GOLDSCHMIDT, C. C. Resiliência: Um estudo exploratório da percepção de gestores sobre o constructo, nas dimensões humana e organizacional. 2015. 131 f. Dissertação (Mestrado em Gestão Empresarial) - Escola Brasileira de Administração e de Empresas, Rio de Janeiro, 2015.

HASS, J. Environmental ('green') management typologies: an evaluation, operationalization and empirical development. Business Strategy and the Environment, v. 5, n. 2, p. 59-68, 1996.

HUNT, C.; AUSTER, E. Proactive environmental management: avoiding the toxic trap. Sloan Management Review, v. 31, n. 2, p. 7-18, 1990.

KOLK, A.; MAUSER, A. The evolution of environmental management: from stage models to performance evaluation. Business Strategy and the Environment, v. 11, n. 1, p. 14-31, 2002.
PAULRAJ, A. Environmental motivations: a classification scheme and its impact on environmental strategies and practices. Business Strategy and the Environment, v. 18, n. 7, p. 453-468, 2009.

PORTER, M. E.; KRAMER, M. R. Creating Shared Value. Harvard Business Review, p. 62-77, Jan./Feb. 2011.

RENUKAPPA, S. et al. Drivers for Embedding Sustainability Initiatives within Selected UK Industrial Sectors. Journal of International Real Estate and Construction Studies, v. 3, n. 1, p. 51-72, 2013.

REPORT of the United Nations Conference on Sustainable Development. 2012. Available at: <http://www.uncsd2012.org/ content/documents/814UNCSD\%20REPORT\%20final\%20revs.pdf>. Accessed on: June 25, 2013.

REZAEE, Z. Corporate Sustainability: Theoretical and Integrated Strategic Imperative and Pragmatic Approach. The Journal of Business Inquiry, v. 16, n. 1 (Special Issue), p. 60-87, 2017.

ULH $\varnothing I$, J. P.; ULH $\varnothing I, B$. P. Beyond climate focus and disciplinary myopia: the roles and responsibilities of hospitals and healthcare professionals. International Journal of Environmental Research and Public Health, v. 6, n. 3, p. 1204-1214, 2009.

VASCONCELOS, I. et al. Organizational resilience and sustainable innovation: a study on the human resources management model at a Brazilian energy company. Cad. EBAPE.BR, v. 13, n. 4, p. 910929, 2015

VASTAG, G., KEREKES, S., RONDINELLI, D.A. Evaluation of corporate environmental management approaches: a framework and application. International Journal of Production Economics, v. 43, n. 2-3, p. 193-211, 1996.

WINN, M.; ANGELL, L. Towards a process model of corporate greening. Organization Studies, v. 21, n. 6, p. 1119-1147, 2000.

ZADEH, R.; XUAN X.; SHEPLEY, M. Sustainable healthcare design: Existing challenges and future directions for an environmental, economic, and social approach to sustainability. Facilities, v. 34 n. 5/6, p.264-288, 2016.

YIN, R. K. Case study research: design and methods. London: Sage, 2014

Jan Krüger

Master in Business Administration at the COPPEAD Graduate School of Business, Universidade Federal do Rio de Janeiro - COPPEAD / UFRJ, Rio de Janeiro, RJ, Brazil. Email: jankruger@gmail.com

Claudia Araujo

PhD in Business Administration at the COPPEAD Graduate School of Business, Universidade Federal do Rio de Janeiro - COPPEAD / UFRJ. Rio de Janeiro, RJ, Brazil.E-mail: claraujo@coppead.ufrj.br

Guilherme Curi

PhD student at the Postgraduate Program in Communication and Culture of the Universidade Federal do Rio de Janeiro (PPGCOM-UFRJ). Master in Sociology at University College Dublin (UCD). Researcher at the Center for Studies in Health Services Management (CESS / COPPEAD / UFRJ), Rio de Janeiro, Brazil. E-mail: curi.guilherme@gmail.com 